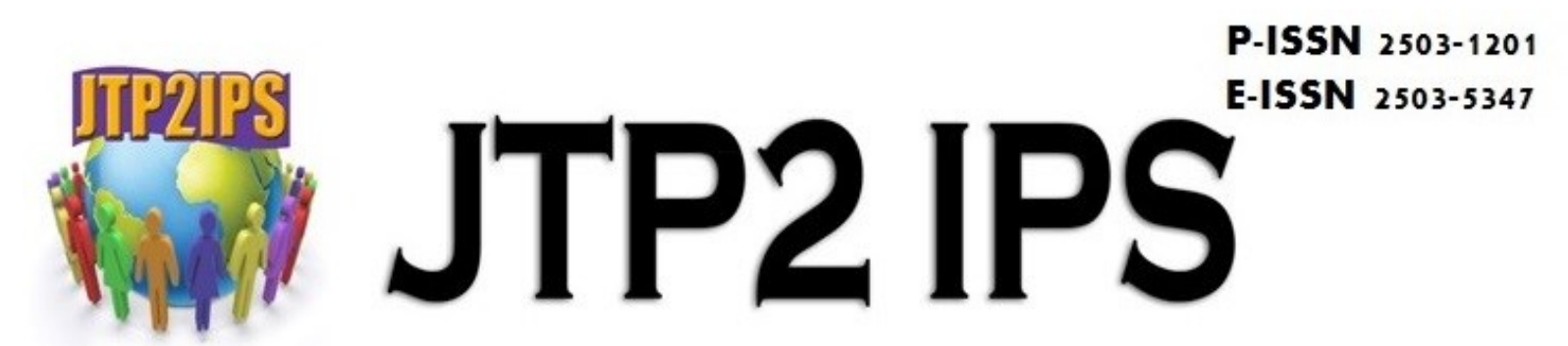

\title{
PENINGKATAN AKTIVITAS DAN HASIL BELAJAR IPS SISWA DENGAN MENGGUNAKAN MEDIA PEMBELAJARAN “JENDELA HIDROSFER”
}

\section{Martina Lona Jusita ${ }^{1}$}

\begin{abstract}
Abstrak
Materi hidrosfer berkait dengan siklus hidrologi, bentuk-bentuk tubuh air, dan zona laut menurut kedalaman sebagai objek material IPS terlalu sulit dipahami bila hanya mengandalkan transfer ilmu dari guru kepada peserta didik; lebih baik bila peserta didik dapat melihat apa yang diamati, yang kemudian ditulis dan akhirnya dipresentasikan berdasarkan pengalaman belajarnya. Dengan demikian diperlukan suatu media sebagai perantara yang dapat membantu proses belajar. Untuk itu, media pembelajaran yang sesuai adalah dengan menggunakan "Jendela Hidrosfer". Media pembelajaran bukan sekadar sebagai perantara semata; melainkan mampu meningkatkan aktivitas dan hasil belajar peserta didik.
\end{abstract}

Kata kunci: Aktivitas belajar, Hasil belajar, Media pembelajaran "Jendela Hidrosfer"

\begin{abstract}
Hydrosphere material related to the hydrological cycle, forms the body of water, and marine zones according to depth as a material object IPS too elusive if only rely on the transfer of knowledge from the teacher to the learner; better if the students can see what is observed, which is then written and finally presented based learning experiences. Thus we need a media as an intermediary to help the learning process. To that end, the appropriate learning media is to use the "Jendela Hidrosfer". Medium of learning not just as a mere intermediary; but can increase the activity and learning outcomes of students.

Keywords: Learning activities, Learning outcomes, Instructional media "Jendela Hidorsfer"
\end{abstract}

\footnotetext{
${ }^{1}$ SMP Negeri 2 Ngantang Kabupaten Malang_martinalonajusita@gmail.com
} 


\section{PENDAHULUAN}

Pembelajaran IPS dengan objek material yang terkait dengan fenomena geosfer dan objek formal berupa kajian keruangan dalam konteks kelingkungan; kedua objek tersebut menekankan pada gejala-gejala yang terjadi di muka bumi. Materi hodrosfer merupakan salah satu dari fenomena geosfer. Pemahaman materi hidrosfer berkait dengan siklus hidrologi, bentuk-bentuk tubuh air, dan zona laut menurut kedalaman sebagai objek material. Fenomena hidrosfer terlalu sulit dipahami bila hanya mengandalkan transfer ilmu dari guru kepada peserta didik yang bersifat verbalistis semata. Lebih baik peserta didik dapat melihat secara langsung yang kemudian ditulis dan dipresentasikan berdasarkan pengalaman belajarnya sendiri.

Karakteristik materi hidrosfer membutuhkan suatu media sebagai perantara yang menyampaikan pesan-pesan berupa materi pembelajaran yang berasal dari guru serta dilaksanakan di dalam kelas yang dapat membantu proses belajar. Alangkah lebih baik jika guru dapat merangkai media yang dapat mencakup materi yang berkaitan dengan fenomena hidrosfer secara lengkap. Diharapkan dari satu produk akan mencakup seluruh materi yang menjadi tujuan pembelajaran.

Menurut Winkel (1999) bahwa media pengajaran sebagai sarana nonpersonal yang digunakan oleh tenaga pengajar yang memegang peranan dalam proses belajar mengajar untuk mencapai tujuan instruksional. Media yang dikembangkan berupa rangkaian gambar dalam ukuran $2 \times 1 \mathrm{~m}$ yang dapat diputar naik turun sesuai kebutuhan serta dimasukkan kotak yang dapat dibuka dan ditutup pada tiap sisinya. Pemberian warnawarna yang menarik dengan menyesuaikan konten materi seperti (1) siklus hidrologi, (2) terjadinya penguapan air, atau (3) tentang cuaca dan iklim. Pemberian warna yang menarik diharapkan dapat memikat peserta didik dan dapat menggerakkan minat untuk mengikuti pembelajaran. Tidak kalah pentingnya, simbol-simbol gambar disertakan agar memperkuat kesan dan menonjolkan proses serta kenampakan alam yang berlangsung agar dapat memperjelas pesan pembelajaran.

Media pembelajaran hendaknya dapat digunakan sebagai sarana untuk mengembangkan aktivitas belajar peserta didik. Akti- vitas mengarah pada kegiatan yang memiliki tujuan tertentu (Rooijakkers, 1993) yang akhirnya dapat mencapai tujuan belajar pada tahap selanjutnya adalah menemukan kembali informasi baru yang pernah diterima dari guru dengan mengembangkan secara lebih mendalam dan bermakna. Aktivitas belajar peserta didik akan tampak saat mengikuti kegiatan pembelajaran sampai akhirnya mendorong peserta didik memahami materi yang akhirnya dapat meningkatkan hasil belajarnya. Cara mengukur hasil belajar peserta didik dilakukan dengan tes hasil belajar. Gagne (1977) mengemukakan hasil belajar sebagai kapabilitas berupa kemampuan yang dapat diamati. Tes hasil belajar merupakan proses untuk menentukan nilai belajar dari proses pembelajaran yang telah dilaksanakan.

\section{METODE}

Penelitian ini merupakan penelitian tindakan kelas yang diadaptasi dari model spiral Kemmis \& Mc. Taggart. Dalam prosesnya, peneliti berpartisipasi langsung dari awal hingga akhir. Peneliti berusaha memahami apa yang terjadi sambil terlibat dalam sebuah proses perubahan dan perbaikan (Wiriaatmadja, 2005).

Waktu penelitian dilakukan mulai minggu kedua Februari 2016 sampai dengan minggu pertama April 2016 bertempat di SMP Negeri 2 Ngantang Kabupaten Malang. Subjek penelitian siswa kelas VII-D sejumlah 32 orang, dengan rincian sejumlah 16 orang laki-laki dan 16 orang perempuan. Pengumpulan data dengan menggunakan (1) lembar observasi aktivitas belajar, dan (2) tes hasil belajar. Prosedur penelitian meliputi: (1) tahap pratindakan, dan (2) tahap pelaksanaan tindakan yang terdiri dari tiga siklus. Setiap siklus dilakukan perencanaan (plan), pelaksanaan (action), observasi (observation), dan refleksi hasil tindakan (reflection).

Langkah-langkah kegiatan selengkapnya diawali dengan menyiapkan instrumen penelitian, menyusun Rencana Pelaksanaan Pembelajaran (RPP), dan membuat media pembelajaran "Jendela Hidrosfer". Dalam pelaksanaan pembelajaran pada materi hidrosfer dengan menggunakan media pembelajaran "Jendela Hidrosfer" sekaligus mengamati dan mendokumentasikan data-data yang berkaitan dengan aktivitas dan hasil belajar IPS peserta 
didik selama proses pembelajaran berlangsung. Guru menjelaskan materi hidrosfer, selanjutnya peserta didik melakukan kegiatan diskusi secara kelompok. Setelah selesai kemudian mempresentasikan ke depan kelas hasil diskusinya dan kelompok lain menanggapinya.
Sebagai akhir kegiatan adalah melakukan refleksi untuk melihat hasil pelaksanaan pembelajaran sebagai bahan merencanakan tindakan pada siklus berikutnya. Berikut adalah gambaran siklus Penelitian Tindakan Kelas yang di maksudkan di atas.

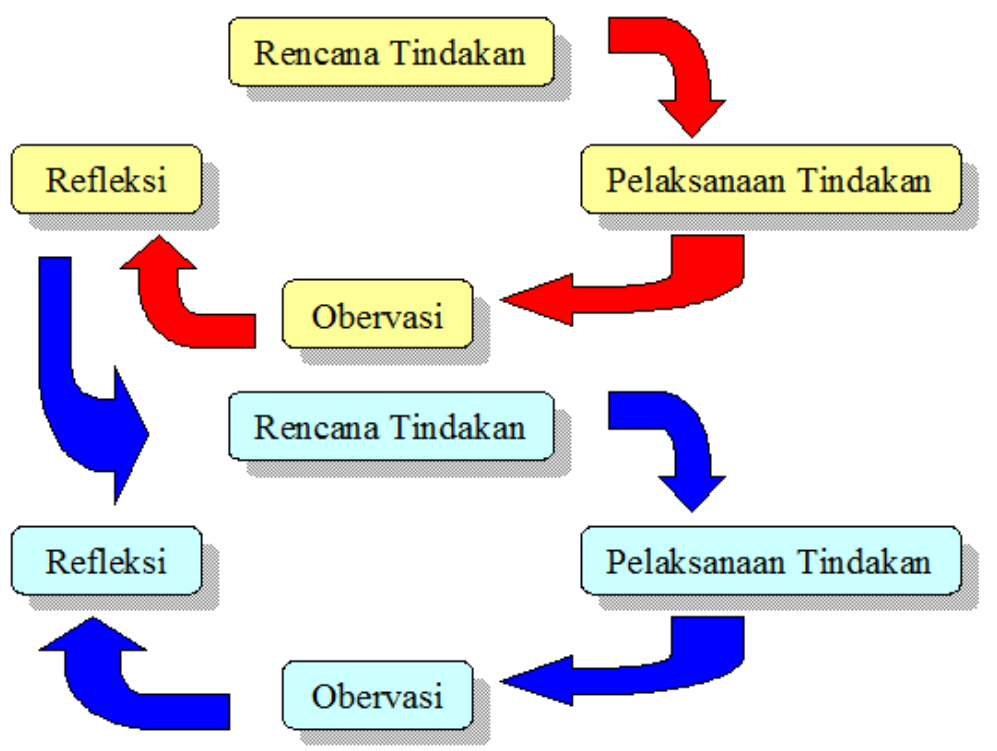

Gambar 1. Siklus Penelitian Tindakan Kelas Kemmis \& Mc. Taggart

\section{HASIL}

Berdasarkan hasil observasi pendahuluan aktivitas belajar peserta didik dalam kategori kurang dengan rerata 36,5. Sejumlah 17 peserta didik $(53,13 \%)$ menunjukkan aktivitas belajar rendah yang ditandai dengan menunjukkan tidak perhatian pada sebagian besar waktu belajar, tidak tertarik dengan penjelasan yang diberikan oleh guru, dan kurang menunjukkan minat dalam belajar. Selain itu, hasil belajar peserta didik kelas VII-D tergolong rendah dengan rerata hasil belajar 60,25, sejumlah 25 peserta didik $(78,13 \%)$ menunjukkan hasil belajar di bawah Kriteria Ketuntasan Minimal (KKM).

Tabel 1. Aktivitas Belajar

\begin{tabular}{lcccccccc}
\hline \multirow{2}{*}{ Kriteria } & \multicolumn{2}{c}{ Observasi awal } & \multicolumn{2}{c}{ Siklus I } & \multicolumn{2}{c}{ Siklus II } & \multicolumn{2}{c}{ Siklus III } \\
\cline { 2 - 10 } & $\begin{array}{c}\text { Jumlah peserta } \\
\text { didik }\end{array}$ & $\%$ & $\begin{array}{c}\text { Jumlah peserta } \\
\text { didik }\end{array}$ & $\%$ & $\begin{array}{c}\text { Jumlah peserta } \\
\text { didik }\end{array}$ & $\%$ & $\begin{array}{c}\text { Jumlah peserta } \\
\text { didik }\end{array}$ & $\%$ \\
\hline Tinggi & 15 & 46,87 & 17 & 53,13 & 23 & 71,87 & 27 & 84,37 \\
Rendah & 17 & 53,13 & 15 & 46,87 & 9 & 28,13 & 5 & 15,63 \\
\hline
\end{tabular}

Setelah dilakukan tindakan dengan menggunakan media pembelajaran "Jendela Hidrosfer" pada Siklus I aktivitas belajar peserta didik mengalami sedikit peningkatan dibandingkan pada saat observasi awal, hanya 15 orang menunjukkan aktivitas belajar rendah dengan persentase keberhasilan tindakan mencapai rerata 59 dalam kategori cukup. Pada Siklus II mengalami peningkatan dari 15 peserta didik menjadi 9 orang yang menun- jukkan aktivitas belajar rendah dengan persentase keberhasilan tindakan mencapai rerata 72 dalam kategori baik. Siklus III melampaui target sejumlah 5 orang saja yang menunjukkan aktivitas belajar rendah dari target sejumlah 7 orang dalam kategori rendah, rerata persentase keberhasilan tindakan mencapai 81 dalam kategori sangat baik. Dengan demikian dikatakan penggunaan media pembelajaran dapat meningkatkan aktivitas belajar. 
Vol.2 No.1 April 2017

P ISSN 2503 - 1201, E ISSN 2503 - 5347

Tabel 2. Taraf Keberhasilan Aktivitas Belajar

\begin{tabular}{|c|c|c|c|c|}
\hline $\begin{array}{c}\text { Persentase Keberhasilan } \\
\text { Tindakan }\end{array}$ & Observasi awal & Siklus I & Siklus II & Siklus III \\
\hline Rerata & 36,5 & 59 & 72 & 81 \\
\hline Kategori & Rendah & Cukup & Baik & Sangat baik \\
\hline
\end{tabular}

Seiring dengan peningkatan aktivitas belajar dari siklus ke siklus. Peningkatan rerata hasil belajar siklus I hanya sedikit dengan rerata 65 dalam kategori cukup. Pada siklus II rerata hasil belajar 73,25 (kategori cukup), dan Siklus III rerata menunjukkan 81,72 (kategori sangat baik).

Tabel 3. Hasil Belajar

\begin{tabular}{lcccc}
\hline \multicolumn{1}{c}{ Hasil } & Observasi awal & Siklus I & Siklus II & Siklus III \\
\hline Rerata & 60,25 & 65 & 73,25 & 81,72 \\
Kategori & Kurang & Cukup & Baik & Sangat baik \\
\hline
\end{tabular}

Hasil penelitian pada Siklus I aktivitas belajar hanya meningkat sedikit yang disebabkan peserta didik terlalu menikmati gambar-gambar yang disajikan dan waktu untuk diskusi kelompok hanya sedikit serta hanya didominasi oleh dua dari delapan kelompok; dengan demikian pemahaman peserta didik terhadap materi sangat sedikit dan tentunya saat dilakukan pengukuran hasil belajar IPS menunjukkan peningkatan yang sedikit pula. Untuk itu, guru perlu memperbaiki pembelajaran pada Siklus II.

Pada Siklus II aktivitas belajar meningkat karena peserta didik mulai aktif berdiskusi untuk menganalisa gambar dan lebih bisa mengatur waktu dan presentasi hasil diskusi mulai tampak tidak hanya didominasi kelompok tertentu. Pemahaman materi lebih baik dengan demikian hasil belajar mengalami peningkatan secara signifikan. Siklus III melampaui target karena proses pembelajaran berjalan lancar dan peserta didik sangat menikmati, saat dilakukan tes hasilnya melebihi target yang ditetapkan (rata-ratanya $81,72)$ yaitu 75 .

\section{PENUTUP}

Berdasarkan hasil penelitian membuktikan bahwa penggunaan media pembelajaran "Jendela Hidrosfer" mampu meningkatkan aktivitas belajar peserta didik. Terbukti dari masingmasing siklus menunjukkan peningkatan se- cara signifikan dalam aktivitas dan hasil belajar peserta didik. Aktivitas belajar pada Siklus I yang semula 17 orang $(53,13 \%)$ menunjukkan aktivitas belajar tinggi dengan rerata 59 dan kategori taraf keberhasilan cukup, meningkat menjadi 23 orang $(71,87 \%)$ menunjukkan aktivitas belajar tinggi dengan rerata 72 dan kategori taraf keberhasilan baik pada Siklus II, serta pada Siklus III menjadi 27 orang $(84,27 \%)$ menunjukkan aktivitas belajar tinggi dengan rerata 81 dan kategori taraf keberhasilan sangat baik.

Peningkatan hasil belajar secara signifikan seiring dengan peningkatan aktivitas belajarnya. Pada Siklus I rerata hasil belajar hanya 65 dalam kategori cukup, Siklus II dengan rerata 73,25 dalam kategori baik, dan akhirnya rerata hasil belajar pada Siklus III adalah 81,72 dalam kategori sangat baik.

\section{DAFTAR PUSTAKA}

[1] Gagne, R. 1977. The Condition of Learning. Third Edition. Canada: Holt, Rine Hart and Winston.

[2] Rooijakkers. 1993. Mengajar Dengan Sukses. Jakarta: PT. Grasindo

[3] Winkel. 1999. Psikologi Pengajaran. Cetakan kelima. Jakarta: PT Grasindo.

[4] Wiriaatmadja, R. 2005. Metode Penelitian Tindakan Kelas untuk Meningkatkan Kinerja Guru dan Dosen. Bandung: PT Remaja Rosda Karya. 